\title{
Evaluation of Reichert Meissl Values of Butter Produced in Turkey
}

\author{
Serap Kılıç Altun ${ }^{1}$, Nilgün Paksoy² \\ ${ }^{1}$ Department of Food Hygiene and Technology, Faculty of Veterinary Medicine, \\ Harran University, Şanlıurfa, 63200, Turkey \\ ${ }^{2}$ Department of Biochemistry, Faculty of Veterinary Medicine, \\ Harran University, Şanlıurfa, 63200, Turkey \\ Corresponding Author: Nilgün Paksoy, Harran University, Şanlıurfa, 63200, Turkey
}

\begin{abstract}
:
Butter is a high-quality dairy product which has nutritious value and special taste. The purpose of this research was to evaluate the Reichert-Meissl values of the butter samples produced in Turkey. 120 butter samples were collected as study material in 2015. The Reichert-Meissl values of the butter samples were determined in accordance with the Turkish Standard (TS1331). The mean Reichert-Meissl values of butter samples were $25.35 \pm 6.76$. The highest Reichert-Meissl value was 31.11 was and the lowest ReichertMeissl value was 0.23 in all samples analyzed. When the Reichert-Meissl values of the butter samples were compared with other research results, the average Reichert-Meissl value was in accordance with previous studies. Adequate surveillance programs should be maintained to prevent the impact of food fraud.
\end{abstract}

Keywords: Reichert-Meissl value, butter, Turkey

\section{Introduction}

Milk fat has important nutritional properties due to its essential fatty acids. It is an important milk component, especially because it contains vital fatty acids, has high digestibility, contains fat-soluble vitamins and is dissolved at body temperature. These properties of milk fat also increase the nutritional value of butter. Butter has special nutritional, functional and organoleptic properties (Gosewade et al., 2017). In addition to an amount of water present in the composition of the butter, phospholipids, hydrocarbons, sterols and sterol esters, complex glyceride oils, free fatty acids, oil-soluble vitamins, and minerals (Kumar et al., 2016). Since the production process is different from other milk products, butter has its own texture and taste. Butter is a product that can maintain its freshness for one year under ideal storage conditions. The use of butter made from cow's, sheep's and goat's milk in Turkey generally is a common milk product (Atasoy $\&$ Türkoğlu, 2010). The most economically valuable dairy product is milk fat. The fact that the raw material is only milk fat in the production of butter causes the adulteration with the addition of different low-cost oils to reduce the cost of commercial enterprises (Pradhan, 2016). Of milk fat, butter is the most subjected to adulteration by fractional substitution with diverse types of low-value fat, seeds oil or vegetable fat as margarine (Rotar, 2010). Such frauds in the butter can negatively affect both consumer health and the national dairy industry. According to other researches, it has been found that fat-like milk oils such as palm oil, cotton oil, and margarine are used for adulteration (Pradhan, 2016; Gandhi et al., 2014; Sağdıç et al., 2004). Sensorial testing is not consistently pertinent; however fraudulent butter may include a number of compounds seemingly natural provide with the sensory qualities similar to butter, so only the physicochemical analysis is efficient to identify and certify the adulteration (Rotar, 2010). Determination of physicochemical parameters of the butter gain importance in terms of detecting fraudulent products. Many different methods have been used to determine whether different oils are present in butter content. Some of these are attenuated total reflectance (Mid-Infrared Spectroscopy- ATR-MIR), capillary column gas chromatography (Diraman, 2006), differential scanning calorimetry (DSC) 
(Aktaş \& Kaya, 2001; Koca et al., 2010). While these methods are fast but expensive methods, Reichert-Meissl (RM) value method is still used today as a fast and inexpensive method. RM value is the quantification of short-chain fatty acids soluble in water can be released in overall saponification (Deelstra et al., 2014). The RM value method is based on the detection of volatile fatty acids found only in milk fat, such as butyric acid (C4: 0) and caproic acid (C6: 0) (Pradhan, 2016). The RM value is the amount of $0.1 \mathrm{~N}$ alkaline solution needed for the neutralization of volatile fatty acids by saponification, acidification and steam distillation of $5 \mathrm{~g}$ fat (Sözbilir \& Bayşu, 2008). The value of RM is in the range of 28-35 in the milk fat samples, and it is measured as 7 in the vegetable oils (Kumar et al., 2016). The aim of this study was to determine the value of RM in butter samples produced in Turkey.

\section{Materials and Method}

120 samples of butter were collected from the local markets and were analyzed to detect milk fat adulteration. Butter samples were brought immediately to the laboratory in a $500 \mathrm{~mL}$ glass containers sampling and analyzed on the same day. Butter samples of standard butter prepared from milk provided from the herd of Harran University Agriculture Faculty. Sulphuric acid $\left(\mathrm{H}_{2} \mathrm{SO}_{4}\right)$, sodium hydroxide $(\mathrm{NaOH})$, glycerol, phenolphthalein were purchased from Merck, Germany. After dissolving the butter samples, they were filtered to remove from their water and sediment. 5 grams of the filtered samples were weighed into $250 \mathrm{~mL}$ distillation flask. $20 \mathrm{~g}$ of glycerol and $2 \mathrm{~mL}$ of $44 \%$ $\mathrm{NaOH}$ solution were added. At this stage, the samples were destroyed to saponify, and the liquid returned to the lemon yellow was agitated by heating until clear. The flask was cooled to $90^{\circ} \mathrm{C}$. $90 \mathrm{~mL}$ of distilled water was added and stirred. Cooling water was opened by placing a flask on the distillation collection section of the distillation device. To facilitate boiling, 0.6-0.7 $\mathrm{g}$ of powdered pumice was placed on the soap solution. Then, $50 \mathrm{~mL}$ of $1 \mathrm{~N}$ $\mathrm{H}_{2} \mathrm{SO}_{4}$ solution was added and placed in the distillation apparatus and distilled by boiling in such a way that $110 \mathrm{~mL}$ of distillate was collected over an average of 20 minutes. The heating was terminated when the distillation approached $110 \mathrm{~mL}$ and was completed with the last droplets to $110 \mathrm{~mL}$ of the marker line. The mouth of the flask was sealed and placed in a water bath at $20 \mathrm{oC}$, with a $110 \mathrm{~mL}$ marking a line in the water and allowed to stand at this temperature for 10 to 15 minutes. If the level dropped at the end of the line, it was completed with $110 \mathrm{~mL}$ line with pure water. Distillate was filtered through a filter paper into a $100 \mathrm{~mL}$ graduated flask. $100 \mathrm{~mL}$ of the filtrate was titrated with phenolphthalein and $0.1 \mathrm{~N} \mathrm{NaOH}$. Control was carried out without fat and the control at the end of the experiment was removed from the total consumption (Anonymous, 1995).

\section{Calculation}

$\mathrm{RM}$ Value $=\left(\mathrm{V}_{1}-\mathrm{V}_{0}\right) \times \mathrm{N} \times \mathrm{f} \times 11$

$\mathrm{V}_{1}: \mathrm{NaOH}$ solution volume spent in the experiment, $\mathrm{mL}$

$\mathrm{V}_{0}$ : The volume of $\mathrm{NaOH}$ solution spent in the experiment, $\mathrm{mL}$

$\mathrm{N}$ : Normality of $\mathrm{NaOH}$ solution used in titration

$\mathrm{f}$ : the factor of $\mathrm{NaOH}$ solution used in titration

\section{Results and Discussion}

The RM value of standard butter sample was 26.01. The RM values of the analyzed samples were shown in Table 1. The mean RM value of butter samples was $25.35 \pm 6.76$. The highest Reichert-Meissl value was 31.11 was and the lowest Reichert-Meissl value was 0.23 in all samples analyzed.

Table 1: Descriptive statistics of RM values

\begin{tabular}{llccc}
\hline Sample $\mathrm{n}$ & Minimum & Maximum & Mean \pm SD \\
& & & & \\
\hline Butter & 120 & 0.23 & 31.11 & $18.90 \pm 7.17$
\end{tabular}

SD: Standard deviation

In a survey conducted with 15 butter samples in 1993, RM values were between 22.65-28.40 and the lowest value was higher than the lowest value in our study and the highest value was close to the highest value in our study (Yalçın et al., 1993). In a research, authors reported that RM value of cow ghee varies between 26-29 and RM value of buffalo and sheep gee have is higher approximately 32 (Ganguli \& Jain, 1973). The average value of the ghee samples is higher than this study's average value because of ghee's fat rate is higher than butter. In India, the study conducted by Pradhan (2016) revealed that the value of RM in the ghee samples from cow's milk ranged from 27.39 to 28.71 and the 
average value was 28.01. It was reported by the researcher that the pure palm oil had 0.11-0.22, the pure soybean oil had 0.11-0.33, the canola oil had a 0.11-0.22 RM value. The researcher reported that it was easy and reliable to determine the RM value of vegetable oils added for adulteration purposes by $1.5 \%$ or more (Pradhan, 2016). Gandhi et al.'s study (2014) of added palm oil and sheep's internal fat in ghee samples, researchers reported that the value of RM of ghee samples produced from pure cow's milk was 29.50, and the value of RM of ghee samples produced from pure buffalo milk was 33.30 on average. When they added palm oil and $21 \%$ sheep internal fat, they reported that the value of RM was 23.87 in the ghee samples produced from cow's milk and 26.51 in the ghee samples produced from buffalo milk (Gandhi et al., 2014). In 2016, the value of RM in a study conducted by ghee samples in Meerut province of India, RM values were in the range of 28.00-40.20 and the average RM value was 34.10 (Kumar et al., 2016). Çelik and Bakırcı (2000) reported that $\mathrm{RM}$ values of butter samples obtained from small dairies and family plants changed between 11.62-28.51 and 22.70-29.75 and mean values were $26.86 \pm 0.86$ and $22.97 \pm 0.17$, respectively. The results obtained by researchers were parallel with our results. Peter \& Kron (1932) declared that RM values of butter samples obtained from Hungary ranged between 25.0-27.5. Gosewade et al. (2017) reported that the RM value of cow and buffalo ghee samples ranged between 29.48-30.25 and 33.22-34.43, with a mean level of 29.95 and 33.91, respectively. In another study from Turkey, RM values varied from 25.57 to 26.68 in butter samples and the highest values had sheep, goat, and cow butter samples, respectively (Kahyaoğlu \& Çakmakçı, 2018).

\section{Conclusion}

In conclusion, from the results obtained in this research, the mean RM value of butter samples was $25.35 \pm 6.76$. When the RM values of the butter samples were compared with other researcher results, the average RM value was in accordance with previous studies. Standard surveillance programmes might be pursued for healthy value requested in the butter. Also when determining adulteration of butter we recommend determination $\mathrm{RM}$ value as a fast and reliable method.

\section{References}

[1] Aktaş, N., \& Kaya, M. (2001). Detection of beef body fat and margarine in butterfat by differential scanning calorimetry. Journal of Thermal Analysis and Calorimetry, 66, pp. 795-801.

[2] Anonymus (1995). Türk Standartları Enstitüsü. Tereyağı. TS 1331, T.S.E., Ankara

[3] Atasoy, A.F., \& Türkoğlu H (2010). Şanlıurfa'da Üretilen Ve Satışa Sunulan Sadeyağların (Urfa Yağı) Serbest Yağ Asitleri Bileşiminin Belirlenmesi Üzerine Bir Araştırma. Harran Tarım ve Gıda Bilimleri Dergisi, 14(2), pp. 9-12.

[4] Çelik, Ş., \& Bakirci, İ. (2000). A Study on the Physical and Chemical Properties of CookeryType Butter. Pakistan Journal of Biological Sciences, 3(4), 596-598.

[5] Deelstra, H., Burns, D.T., \& Walker, M.J. (2014). The adulteration of food, lessons from the past, with reference to butter, margarine and fraud. European Food Research and Technology, 239(5), pp. 725-744.

[6] Diraman, H. (2006). Tereyağı ve zeytinyağında muhtemel tağşişlerin kapiler kolon gaz kromatografisi yöntemi kullanılarak CisTrans yağ asitleri düzeyi ile belirlenmesi üzerine bir çalışma. Academic Food Journal, 4(23), pp. 3-10.

[7] Gandhi, K., Upadhyay, N., Aghav, A.D., Shanna, V., \& Lal, D. (2014). Detection of adulteration of ghee (clarified milk fat) with palmolein and sheep body fat using ReichertMeissl (R.M.) value coupled with solvent fractionation technique. Indian Journal of Dairy Science, 67(5), pp. 387-393.

[8] Ganguli, N.C., \& Jain, M.K. (1973). Ghee: Its chemistry, processing and technology. Journal of Dairy Science, 56(1), pp. 19-25.

[9] Gosewade, S., Gandhi, K., Ranvir, S., Kumar, A., \& Lal, D. (2017). A study on the physicochemical changes occurring in ghee (butter oil) during storage. Indian J Dairy Sci, 70(1), 81-88.

[10] Kahyaoğlu, D.T., \& Çakmakçı, S. (2018). A Comparative Study On Some Properties And Oxidation Stability During Storage Of Butter Produced From Different Animals'milk. GIDA/The Journal of FOOD, 43(2), pp. 283-293.

[11] Koca, N., Kocaoglu-Vurma, N.A., Harper, W.J., \& Rodriguez- Saona, L.E. (2010). Application of temperature controlled attenuated total reflectance-mid-infrared

(ATR-MIR) spectroscopy for rapid estimation of butter adulteration. Food Chemistry, 121, pp. 778782. 
[12] Kumar, A., Goyal, S.K., Munesh, Kumar, V., \&Kumar, L. (2016). Study of physicochemical analysis of ghee. South Asian Journal of Food Technolgy and Environment, 2(3\&4), pp. 448-451.

[13] Peter, A., \& Kron, S. (1932). Changes in Reichert-Meissl, Polenske, refractometer, and iodine values in Hungarian butter with season and diet, and the relationships between the butter fat constants. Milchwirtschaftliche Forschungen, 14, pp. 378-386.

[14] Pradhan, P. (2016). Effect of addition of palm oil, rapeseedoil, soyabean oil on reichert meissl value of cow milk fat. Doctoral dissertation, Kolkata.

[15] Rotar, R. (2010). Study On Identifying Butter Faking By Substitution With Pork Fat Or With Margarine. Journal Food and Environment
Safety of the Suceava University - FOOD ENGINEERING, 9 (1), pp.40-45.

[16] Sağdıç, O., Dönmez, M., \& Demirci, M. (2004). Comparison of characteristics and fatty acid profiles of traditional Turkish yayik butters produced from goats', ewes' or cows' milk. Food Control, 15(6), pp. 485-490.

[17] Sözbilir, N.B., \& Bayşu, N. (2008). Biyokimya. p.136. Güneş Tip Kitabevleri, Ankara.

[18] Yalçın, S., Tekinşen, O.C., Doğruer, Y., \& Gürbüz, Ü. (1993). Konya'da Tüketime Sunulan Tereyağlarının Kalitesi. Selçuk Üniversitesi Veteriner Fakültesi Dergisi, 9(2), pp. 20-21. 